\title{
Community structure of amphipods on shallow Posidonia oceanica meadows off Tunisian coasts
}

\author{
Rym Zakhama-Sraieb • Yassine Ramzi Sghaier • \\ Faouzia Charfi-Cheikhrouha
}

Received: 31 March 2010 / Revised: 29 June 2010 / Accepted: 13 July 2010 / Published online: 29 July 2010

(C) Springer-Verlag and AWI 2010

\begin{abstract}
The structure, diversity and spatial distribution of the amphipod fauna associated with Posidonia oceanica meadows were studied along the Tunisian coasts in 2007. Samples were collected in nine different meadows at $2 \mathrm{~m}$ depth. A total of 44 species belonging to 12 families were collected. The most common species in terms of abundance were Ampithoe helleri, Hyale camptonyx and Ericthonius punctatus. The highest values of abundance and species richness and the lowest values of diversity and equitability were found in meadows with high epiphyte biomass. Multivariate analyses of data indicated that epiphyte biomass and geographical position were major determinants of the distribution and composition of amphipod assemblages along Tunisian coasts. The presence of two lessepsian amphipod species in one of the southern Posidonia oceanica meadows modified the structure of assemblage.
\end{abstract}

Keywords Amphipoda Posidonia oceanica Tunisia · Epiphyte

\section{Introduction}

Posidonia oceanica, endemic magnoliophyte species in the Mediterranean Sea, is the most abundant and widely distributed seagrass species along the Tunisian coasts. Posidonia oceanica meadows constitute a very important

Communicated by Kurt Thomas Jensen.

R. Zakhama-Sraieb $(\bowtie) \cdot$ Y. R. Sghaier · F. Charfi-Cheikhrouha Faculté des Sciences de Tunis,

Unité de Recherche de Biologie Animale et Systématique

Evolutive, Campus Universitaire, 2092 Manar II, Tunisie

e-mail: zakhamarym@yahoo.fr ecosystem for benthic communities, providing habitat, protection and trophic resources for many species (Boudouresque et al. 2006).

Amphipod crustaceans, for example, are one of the most abundant groups associated with Posidonia oceanica seagrass (Chessa et al. 1983; Gambi et al. 1992; ZakhamaSraieb et al. 2006a) where they reach a high biodiversity (Ledoyer 1966; Scipione and Fresi 1984; Gambi et al. 1992; Scipione et al. 1996; Zakhama-Sraieb et al. 2006b). They are also able to colonize different microenvironments and constitute an important link in trophic webs from producers to higher consumers (Bell and Harmelin-Vivien 1983; Virnstein 1987; Scipione and Mazzella 1992). They are highly dominant in coastal benthos and have long been known as sensitive environmental indicators (Thomas 1993). Many studies (Bellan Santini 1980, 1981; Conradi et al. 1997; Gomez Gesteira and Dauvin 2000; GuerraGarcia and Garcia-Gomez 2001) have shown that amphipods are a very useful group in environmental studies, being good bioindicators of pollution in marine ecosystems.

The amphipod fauna of the Tunisian coast has been relatively unexplored. Following research on Tunisian amphipods conducted up to the beginning of the twentieth century (Chevreux 1910, 1911), a long interval ensued until our recent work (Zakhama-Sraieb et al. 2006a, b, 2008, 2009, 2010).

Several studies were conducted to identify the amphipod fauna inhabiting Posidonia oceanica meadows in the Mediterranean Sea, mainly along the northern shore (Scipione 1998; Scipione and Fresi 1984; Scipione et al. 1983, 1996; Diviacco 1988; Gambi et al. 1992; Sanchez Jerez et al. 1999). However, similar data are scarce and fragmented along the southern coasts. To rectify this lack of information, we conducted the present study which aims at: (1) analysing the composition and the structure of amphipod 
fauna in different Posidonia oceanica meadows distributed along Tunisian coasts; (2) investigating the potential relationships between the amphipod community composition and Posidonia oceanica features, and finally, (3) comparing our results with those carried along the northern shore of the Mediterranean Sea.

\section{Materials and methods}

Study sites

Sampling was carried out in July 2007 (between 15 and 23 of July) at the same depth $(2 \mathrm{~m})$ at $9 \mathrm{pm}$ in order to avoid time and depth-related effects. A total of nine localities distributed along the Tunisian coast (Fig. 1) were selected: Tabarka, Bizerte and Rafraf in the North, Hergla, El Kantaoui, Monastir and Mahdia in the East and Zarzis Ogla and Zarzis plage Sonia in the South. In each selected locality, shallow Posidonia oceanica meadows covered the bottom beginning at $0.5-1 \mathrm{~m}$ depth.

\section{Sampling procedure}

Shoot density was estimated in situ by counting the number of shoots present in a $40 \times 40 \mathrm{~cm}$ quadrat with ten replicates. Concurrently, twenty Posidonia oceanica shoots were randomly collected. In the laboratory, the leaves of each shoot were removed and their length and the width measured. The Leaf Area Index, corresponding to the leaf surface area of Posidonia oceanica for $1 \mathrm{~m}^{2}$ of surface $\left(\mathrm{m}^{2} \mathrm{~m}^{-2}\right)$, was also calculated. After that, the epiphytic biomass was estimated by scraping epiphytes from the leaves using a razor blade and weighing it after being dried in an oven at $70^{\circ} \mathrm{C}$ for $48 \mathrm{~h}$. Epiphytes biomass is expressed in $\mathrm{g} . \mathrm{m}^{-2}$.
In order to sample the amphipods associated to Posidonia oceanica, a box quadrat of $30 \times 30 \mathrm{~cm}$ and $25 \mathrm{~cm}$ depth was used and placed in each Posidonia meadow. The shoots were pulled up and collected in a bag (net size $0.3 \mathrm{~mm}$ ). Three replicates were done at each site. The collected Posidonia oceanica shoots were washed with fresh water over a $0.5-\mathrm{mm}$ sieve. Retained amphipods were sorted, identified to species and counted.

A trophic-guild analysis was done attributing the identified species to trophic categories, according to the literature (Scipione 1998; Gambi et al. 1992), as follows: D, deposit feeders; DS, deposit-suspension feeders; DC, deposit feederscarnivores; Co, commensals; He, herbivores; De, plant detritus feeders; HeD, herbivores-deposit feeders; O, omnivores; U, unknown.

\section{Statistical analysis}

Total abundance $(N)$, number of species $(S)$, the ShannonWiener diversity index $\left(H^{\prime}, \log _{2}\right)$ and Pielou's evenness $(J)$ were calculated for each locality.

The one-way ANOSIM test was used to test differences among Posidonia oceanica features (Density of shoot, LAI, Epiphytes biomass) of different localities with the null hypothesis that there are no significant differences.

Relationships between amphipod assemblages at the nine Posidonia oceanica meadows were investigated using metric multidimensional scaling (MDS) to produce the best graphical descriptions of amphipods community similarities between sites taking in account the total abundances of species at each site. Data were square-root transformed to down weight the contribution of the most abundant species and then converted to a symmetric matrix of biotic similarity between pairs of sites using the Bray-Curtis similarity index. The BIOENV procedure was used to define suites of
Fig. 1 Sampling localities investigated along the Tunisian coasts (1 Tabarka; 2 Bizerte; 3 Rafraf; 4 Hergla; 5 El Kantaoui; 6 Monastir; 7 Mahdia; 8 Zarzis Ogla; 9 Zarzis plage Sonia)
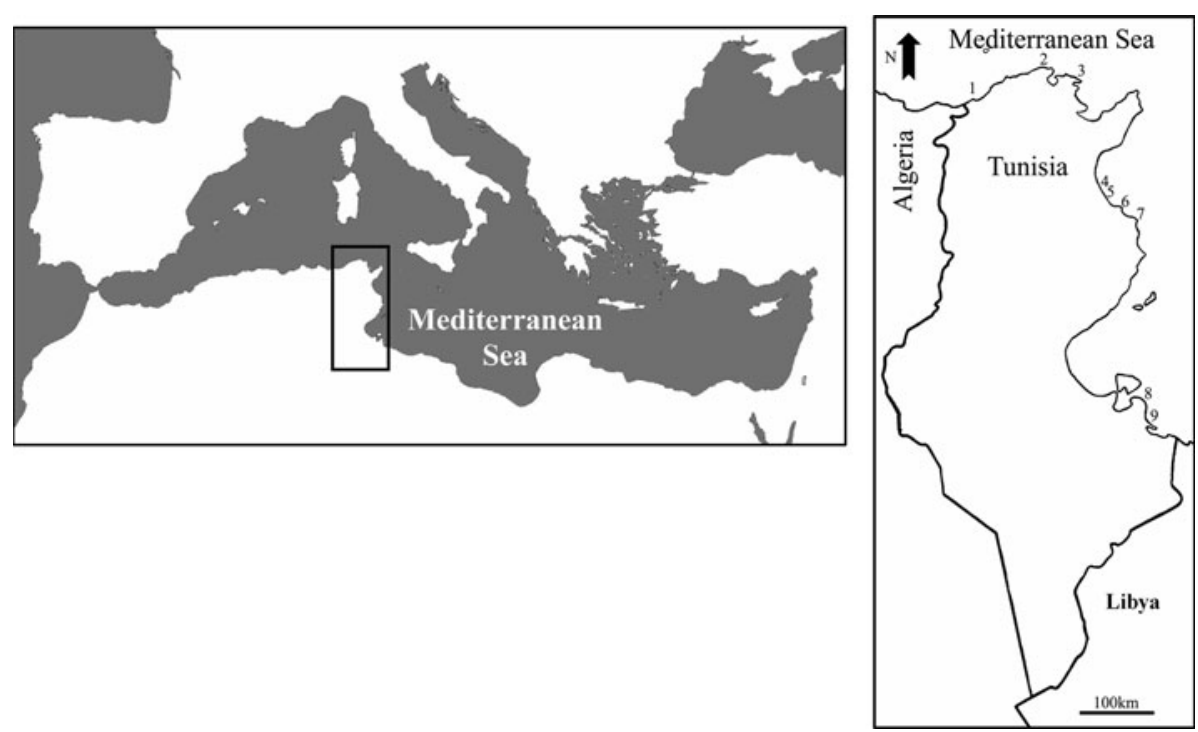
five Posidonia oceanica meadows features (Epiphytes biomass, LAI, Density, Bottom type and Geographical position) that best explain the amphipod fauna assemblage structure. All variables were previously transformed by log $(x+1)$.

The above-mentioned analyses were performed by the PRIMER (Plymouth Routines in Multivariate Ecological Research) software package (Clarke and Warwick 1994).

\section{Results}

Localities and Posidonia oceanica meadows features

The physical characteristics of the nine Posidonia oceanica meadows are shown in Table 1. Morphological features of $P$. oceanica are reported in Fig. 2. At the same depth $(-2 \mathrm{~m})$, shoot density and the same period of the year, LAI and mean epiphytes biomass in the nine meadows were significantly different (ANOVA, $P<0.05$ ). Shoot density and LAI were high in the localities with rocky bottoms (Bizerte, Rafraf, Mahdia and Zarzis plage Sonia). El Kantaoui meadow has the highest values of epiphyte biomass and the lowest shoot density.

Amphipods associated to $P$. oceanica meadows

A total of 12,672 individual amphipods were examined belonging to 16 families and 44 species. The following six species: Ampelisca unidentata, Ampithoe helleri, A. ramondi, Hyale camptonyx, Ericthonius punctatus and Maera inaequipes exhibited a wide distribution in the Tunisian coasts and were collected in the whole of the studied localities: However, twelve species were found in one locality only.

The most dominant species in terms of abundance were Ampithoe helleri with 6,811 individuals (53.75\%), followed by Hyale camptonyx with 1,834 individuals (14.47\%) and

Table 1 Summary table describing the locations and the principal characteristics of the Posidonia oceanica meadows

\begin{tabular}{|c|c|c|c|}
\hline Code & Locality & Location & Bottom \\
\hline TA & Tabarka & $\mathrm{N} 36^{\circ} 57^{\prime}$ E $08^{\circ} 45^{\prime}$ & Sandy \\
\hline BI & Bizerte & $\mathrm{N} 37^{\circ} 12^{\prime} \mathrm{E} 10^{\circ} 12^{\prime}$ & Rocky \\
\hline RA & Rafraf & $\mathrm{N} 37^{\circ} 09^{\prime} \mathrm{E} 10^{\circ} 13^{\prime}$ & Rocky \\
\hline $\mathrm{HE}$ & Hergla & $\mathrm{N} 36^{\circ} 25^{\prime}$ E $10^{\circ} 42^{\prime}$ & Sandy \\
\hline EK & El Kantaoui & $\mathrm{N} 35^{\circ} 53^{\prime} \mathrm{E} 10^{\circ} 36^{\prime}$ & Sandy \\
\hline MO & Monastir & $\mathrm{N} 35^{\circ} 47^{\prime} \mathrm{E} 10^{\circ} 49^{\prime}$ & Sandy \\
\hline MA & Mahdia & $\mathrm{N} 35^{\circ} 30^{\prime} \mathrm{E} 11^{\circ} 04^{\prime}$ & Rocky \\
\hline $\mathrm{ZO}$ & Zarzis Ogla & $\mathrm{N} 33^{\circ} 35^{\prime} \mathrm{E} 11^{\circ} 04^{\prime}$ & Sandy \\
\hline $\mathrm{ZS}$ & Zarzis plage Sonia & $\mathrm{N} 33^{\circ} 31^{\prime} \mathrm{E} 11^{\circ} 07^{\prime}$ & Rocky \\
\hline
\end{tabular}
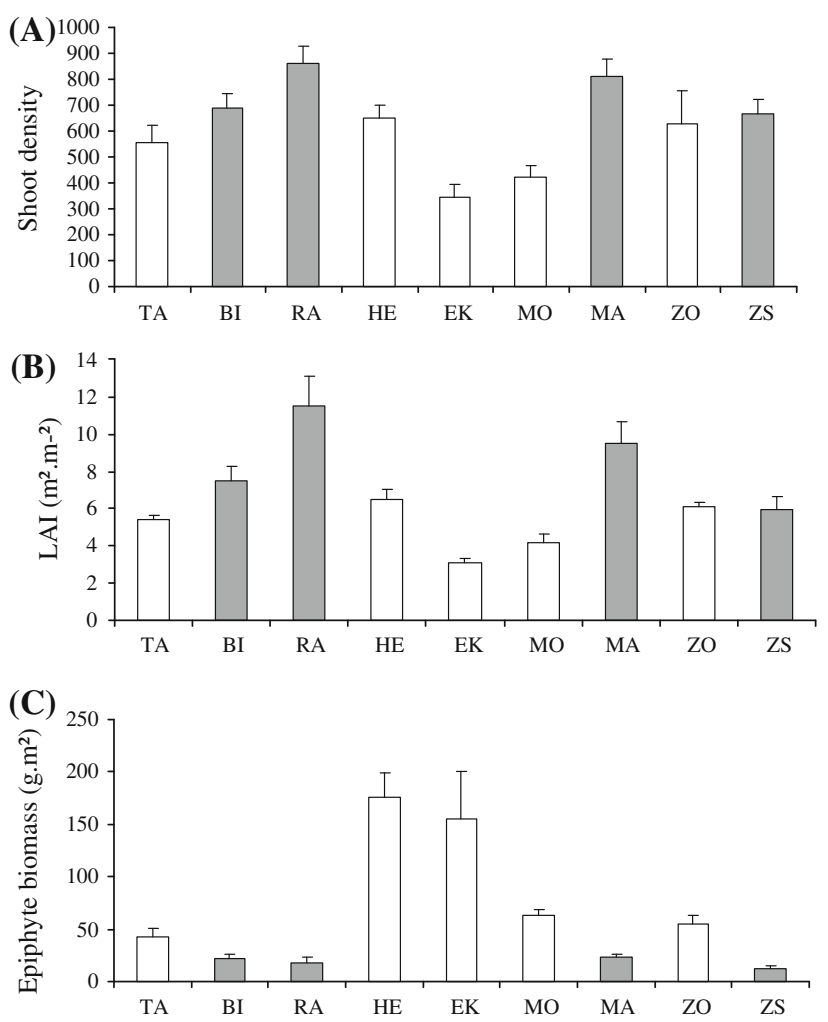

Fig. 2 Variation of mean shoot density (a), LAI (b) and epiphyte biomass (c) in the nine studied Posidonia oceanica meadows (rocky bottom in grey, sandy bottom in white)

Ericthonius punctatus with 1,620 individuals (12.78\%) (Table 2). Ampithoe helleri was the most abundant species in all localities except for Zarzis plage Sonia. Two lessepsian amphipods species were observed in this last locality only and represent their first record for Tunisia (ZakhamaSraieb and Charfi-Cheikhrouha 2010).

Table 2 shows also the number of species, total abundance, diversity and eveness in the nine localities studied. The highest abundance was recorded in Hergla and El Kantaoui with, respectively 2,261 and 2,185 individuals, while the lowest values were observed in Zarzis plage Sonia (612 individuals). The number of species varied between a minimum of 12 species in Zarzis plage Sonia and 26 in Hergla; Shannon-Wiener diversity ranged between 1.29 in El Kantaoui and 3.03 in Rafaraf. Eveness showed low values in meadows exhibiting a high dominance of Ampithoe helleri as El Kantaoui $(J=0.28)$, Hergla $(J=0.44)$ and Monastir $(J=0.48)$.

Dominant feeding guilds in all studied sites were herbivores $(73.87 \%)$ following by deposit-suspension feeders (16.94\%) and omnivores (3.89\%). The other feeding guilds such as herbivores-deposit feeders, deposit feeders, deposit feeders-carnivores, plant detritus feeders and commensals had an almost negligible representation (Fig. 3). Herbivores reached their highest values at El Kantaoui, Monastir and 
Table 2 Abundance of each species (number of individuals per $0.27 \mathrm{~m}^{2}$ of Posidonia oceanica meadow) of the different amphipod species

\begin{tabular}{|c|c|c|c|c|c|c|c|c|c|c|c|}
\hline & t. g. & TA & BI & RA & $\mathrm{HE}$ & EK & MO & MA & $\mathrm{ZO}$ & $\mathrm{ZS}$ & DI \\
\hline Ampelisca rubella A. Costa, 1864 & DS & 24 & 3 & 30 & & & 4 & 13 & & & 0.58 \\
\hline Ampelisca spinipes Boeck, 1861 & DS & 9 & 2 & 3 & & 1 & 2 & 1 & & & 0.14 \\
\hline Ampelisca unidentata (Schellenberg, 1936) & DS & 5 & 2 & 7 & 15 & 1 & 8 & 13 & 35 & 3 & 0.70 \\
\hline Amphilochus neapolitanus Della Valle, 1893 & $\mathrm{U}$ & 15 & 8 & 5 & 6 & 3 & 4 & 18 & 9 & & 0.54 \\
\hline Dexamine spiniventris (A. Costa, 1853) & $\mathrm{HeD}$ & & & & & & & 2 & & & 0.02 \\
\hline Dexamine spinosa (Montagu, 1813) & $\mathrm{HeD}$ & 16 & 9 & 14 & 7 & & 59 & 27 & 5 & & 1.08 \\
\hline Tritaeta gibbosa (Bate, 1862) & $\mathrm{U}$ & 1 & 1 & 8 & 3 & 1 & & 4 & 2 & & 0.16 \\
\hline Hyale camptonyx (Heller, 1866) & $\mathrm{He}$ & 83 & 75 & 245 & 244 & 272 & 200 & 373 & 211 & 131 & 14.47 \\
\hline Parhyale aquilina (A. Costa, 1857) & $\mathrm{He}$ & & & & & 4 & & & & & 0.03 \\
\hline Leucothoe venetiarum Giordani-Soika, 1950 & Co & & & & & & & 2 & & & 0.02 \\
\hline Leucothoe spinicarpa (Abildgaard, 1789) & Co & & & & 1 & 3 & & & & & 0.03 \\
\hline Lysianassa costae (Milne-Edwards, 1830) & $\mathrm{DC}$ & 1 & 11 & & 2 & 2 & 1 & 6 & 2 & 9 & 0.27 \\
\hline Lepidepecreum longicorne (Bate \& Westwood, 1861) & $\mathrm{DC}$ & & & & & 4 & & & & & 0.03 \\
\hline Orchomene humilis (A. Costa, 1853) & DC & & & & 6 & 7 & 3 & & & & 0.13 \\
\hline Socarnes filicornis (Heller, 1866) & $\mathrm{DC}$ & & & & & & & 12 & & & 0.09 \\
\hline Elasmopus brasiliensis (Dana, 1855) & $\mathrm{He}$ & 2 & 14 & 23 & 11 & & & 36 & & 10 & 0.76 \\
\hline Elasmopus pectenicrus (Bate, 1862) & $\mathrm{He}$ & & & & & & & & & 84 & 0.66 \\
\hline Elasmopus pocillimanus (Bate, 1862) & $\mathrm{He}$ & & & & 2 & 3 & 9 & 4 & & & 0.14 \\
\hline Gammarella fucicola (Leach, 1814) & $\mathrm{De}$ & & & & 10 & & & & & & 0.08 \\
\hline Maera hirondellei Chevreux, 1900 & $\mathrm{U}$ & & & 7 & 7 & 4 & 2 & 10 & 20 & 3 & 0.42 \\
\hline Maera inaequipes A. Costa, 1857 & $\mathrm{U}$ & 24 & 31 & 97 & 13 & 13 & 59 & 24 & 67 & 18 & 2.73 \\
\hline Pereionotus testudo (Montagu, 1808) & $\mathrm{He}$ & 3 & & 3 & 3 & & & & & & 0.07 \\
\hline Metaphoxus simplex (Bate, 1857) & $\mathrm{U}$ & & & & 2 & 4 & & & & & 0.05 \\
\hline Stenothoe gallensis Walker, 1904 & $\mathrm{O}$ & & & & & & & & & 125 & 0.99 \\
\hline Stenothoe monoculoides (Montagu, 1813) & $\mathrm{O}$ & & 3 & 5 & 7 & 1 & & 9 & 3 & 6 & 0.27 \\
\hline Aora gracilis (Bate, 1857) & DS & & & & 4 & 5 & 3 & 6 & & & 0.14 \\
\hline Aora spinicornis Afonso, 1976 & DS & & & & 9 & & & & & & 0.07 \\
\hline Lembos websteri Bate, 1857 & $\mathrm{D}$ & 15 & & 30 & & & & & & & 0.36 \\
\hline Lembos sp & $\mathrm{D}$ & & & & & 2 & 25 & 11 & 7 & & 0.36 \\
\hline Leptocheirus guttatus (Grube, 1864) & DS & & & & 14 & 11 & 49 & 32 & & & 0.84 \\
\hline Microdeutopus chelifer (Bate, 1862) & $\mathrm{D}$ & & 34 & 2 & 13 & & & & & & 0.39 \\
\hline Ampithoe helleri G. Karaman, 1975 & $\mathrm{He}$ & 373 & 430 & 335 & 1,190 & 1,700 & 1,615 & 631 & 477 & 60 & 53.75 \\
\hline Ampithoe ramondi Audouin, 1826 & $\mathrm{He}$ & 42 & 106 & 88 & 91 & 60 & 39 & 17 & 30 & 32 & 3.99 \\
\hline Apocorophium acutum (Chevreux, 1908) & DS & & & & & 6 & & & & & 0.05 \\
\hline Caprella acanthifera Leach, 1814 & $\mathrm{O}$ & & & & 10 & 2 & 42 & & & & 0.43 \\
\hline Caprella grandimana Mayer, 1882 & $\mathrm{O}$ & & & 4 & 3 & & & & & & 0.06 \\
\hline Caprella liparotensis Leach, 1814 & $\mathrm{O}$ & & & & 3 & & & & & & 0.02 \\
\hline Deutella schieckei Cavedini, 1982 & $\mathrm{O}$ & 9 & 6 & 12 & & & & & & & 0.21 \\
\hline Pseudoprotella phasma (Montagu, 1804) & $\mathrm{O}$ & & & & & 7 & 32 & 22 & & & 0.48 \\
\hline Ericthonius punctatus (Bate, 1857) & DS & 121 & 335 & 101 & 585 & 68 & 55 & 203 & 21 & 131 & 12.78 \\
\hline Ericthonius difformis Milne-Edwards, 1830 & DS & & & 3 & & 1 & & 3 & & & 0.06 \\
\hline Ischyrocerus inexpectatus Ruffo, 1959 & DS & 18 & 9 & & & & & 2 & & & 0.23 \\
\hline Gammaropsis dentata Chevreux, 1900 & DS & 24 & 64 & 36 & & & & & & & 0.98 \\
\hline \multirow[t]{5}{*}{ Gammaropsis ostroumoui (Sowinsky, 1898) } & DS & & & & & & 47 & & & & 0.37 \\
\hline & $S$ & 18 & 18 & 21 & 26 & 25 & 20 & 25 & 13 & 12 & \\
\hline & $N\left(0.27 \mathrm{~m}^{2}\right)$ & 785 & 1,143 & 1,058 & 2,261 & 2,185 & 2,258 & 1,481 & 889 & 612 & \\
\hline & $H^{\prime}(\log 2)$ & 2.69 & 2.58 & 3.03 & 2.06 & 1.29 & 2.08 & 2.61 & 2.09 & 2.84 & \\
\hline & $J^{\prime}$ & 0.64 & 0.62 & 0.69 & 0.44 & 0.28 & 0.48 & 0.56 & 0.56 & 0.79 & \\
\hline
\end{tabular}

In the table are given the trophic guild (t. g.), $D$, deposit feeders; $D e$, plant detritus feeders; $D C$, deposit feeders-carnivores; $D S$, deposit-suspension feeders; $\mathrm{He}$, herbivores; $\mathrm{HeD}$, herbivores-deposit feeders; $\mathrm{Co}$, commensals; $O$, omnivores; $U$, unknown Number of species $(S)$, total abundance $(N)$, the ShannonWiener diversity index $\left(H^{\prime}, \log 2\right)$ and Pielou's evenness $\left(J^{\prime}\right)$ in the nine studied localities 


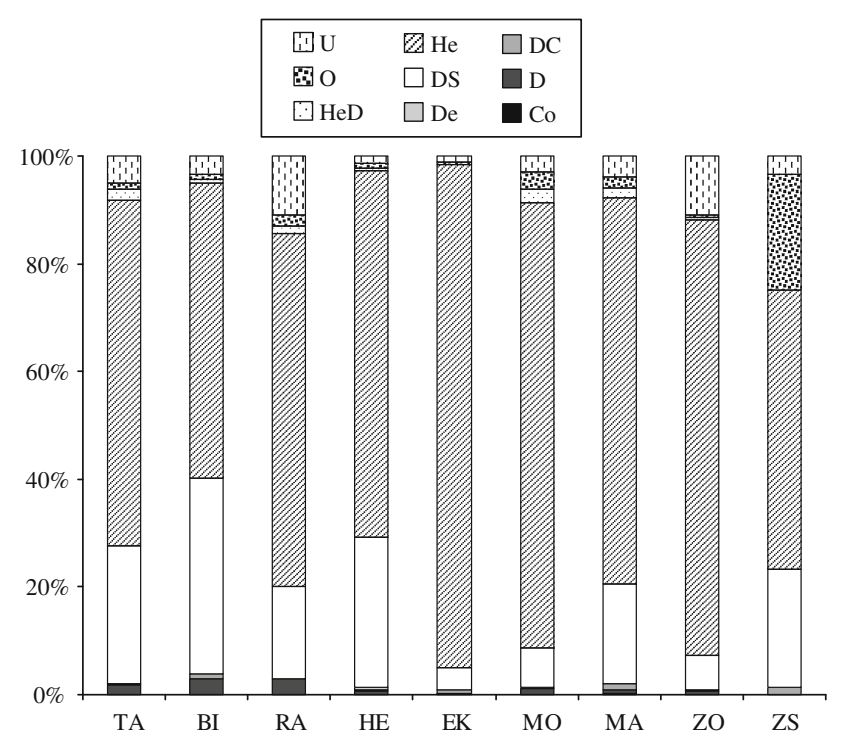

Fig. 3 Percentage of the trophic guilds at the studied $P$. oceanica meadows. $D$, deposit feeders; $D S$, deposit-suspension feeders; $D C$, deposit feeders-carnivores; $\mathrm{Co}$, commensals; $\mathrm{He}$, herbivores; $\mathrm{De}$, plant detritus feeders; $\mathrm{HeD}$, herbivores-deposit feeders; $O$, omnivores; $U$, unknown

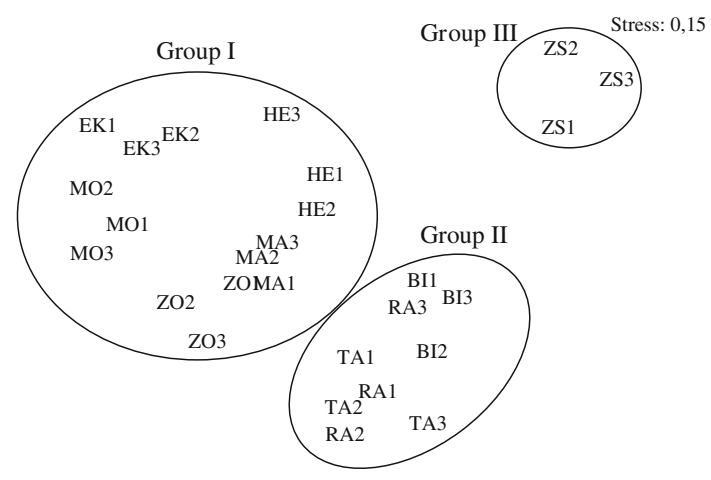

Fig. 4 Multidimensional scaling plot according to species abundance (3 replicates). Stress: 0.16. Legend: $T A$, Tabarka; $B I$, Bizerte; $R A$ : Rafraf; $H E$, Hergla; $E K$, El Kantaoui; $M O$, Monastir; MA, Mahdia; ZO, Zarzis Ogla; ZS, Zarzis plage Sonia

Zarzis El Ogla, mainly represented by the genus Ampithoe and the species Hyale camptonyx.

Relation between species and Posidonia oceanica features

The MDS analysis in Fig. 4 based on the abundance of species performed by pooling the three replicates of each locality, suggests that the amphipod communities could be grouped into three categories: Group I containing the eastern (HE, EK, MO and MA) and a southern locality (ZO), Group II containing the northern localities (TA, BI and RA) and Group III is composed of the three replicates of Zarzis plage Sonia.

The BIOENV procedure revealed most accurately the relationship between the spatial distribution of the
Table 3 Results of BIOENV analyses

\begin{tabular}{lll}
\hline $\begin{array}{l}\text { No. } \\
\text { variable }\end{array}$ & Correlation & Selections \\
\hline 2 & 0.604 & $\begin{array}{l}\text { Epiphyte biomass, geographical position } \\
\text { Epiphyte biomass, geographical position, } \\
\text { shoot density } \\
\text { Epiphyte biomass, geographical position, } \\
\text { bottom type }\end{array}$ \\
3 & 0.593 & $\begin{array}{l}\text { Geographical position, density } \\
\text { Epiphyte biomass, LAI, geographical position } \\
\text { Epiphyte biomass, geographical position, } \\
\text { bottom type, shoot density }\end{array}$ \\
3 & 0.586 & $\begin{array}{c}\text { Epiphyte biomass, LAI, geographical } \\
\text { position, bottom type } \\
\text { Geographical position, bottom type, } \\
\text { shoot density } \\
\text { Epiphyte biomass, LAI, geographical } \\
\text { position, shoot density }\end{array}$ \\
4 & 0.585 & $\begin{array}{c}\text { Epiphyte biomass, LAI, geographical } \\
\text { position, bottom type, shoot density }\end{array}$ \\
4 & 0.575 &
\end{tabular}

amphipods and the Posidonia oceanica meadows features. Analysis showed that the combinations of the Epiphyte biomass and Geographical position (north, east or south) produced the highest degree of correlation between the biotic and environmental data matrices (Table 3).

\section{Discussion}

During this study, a relatively high number of amphipod species have been recorded in Tunisian shallow Posidonia oceanica meadows. A total of 44 species were reported in July 2007, whereas the number of species in each site ranges from 12 to 26 species. This result is similar to other areas of the Mediterranean Sea at the same depth and in the same period of year. For example, Scipione (1998) studied the amphipod fauna of the foliar stratum of Posidonia oceanica from nine stations distributed along the Spanish, Italian and Maltese coasts in July, collecting a total of 45 species. Number of species per site ranged from 9 to 25 ; the highest number ( 25 species) was collected in Porto Conte in Sardinia. Katagan et al. (2001) collected 40 species of amphipods in the shallow Posidonia oceanica meadows off the Aegean Turkey coasts in June and July 1995. Number of species per site ranged from 9 to 15 species.

A group of species (Ampithoe helleri, Hyale camptonyx, Ericthonius punctatus, Ampithoe ramondi, Maera inaequipes, Ampelisca unidentata, Dexamine spinosa, Amphilocus neapolitanus, Maera hirondellei, Lysianassa costae, Stenothoe monoculoides and Tritaeta gibbosa) are common in the studied meadows of Posidonia oceanica in Tunisia. 
The same group of species has often found in P. oceanica meadows elsewhere in the Mediterranean (Scipione and Fresi 1984, Gambi et al. 1992; Scipione et al. 1996, Scipione 1998; Katagan et al. 2001; Mazzella et al. 1989). These species seem to be strongly related to seagrass ecosystems in the Mediterranean Sea. Some of them belong to the "biocoenotic stock of $P$. oceanica" as mentioned by Ledoyer (1962).

Amphipod assemblages differ seasonally at different stations, both in terms of number of species and density in the same depth of water. The abundance and diversity of amphipods is higher in meadows with high epiphyte loading. El Kantaoui and Hergla meadows showed the highest values of epiphyte biomass (EK: 155 g.m ${ }^{-2}$; HE: 175.50 g.m ${ }^{-2}$ ) accompanied by high values of amphipod number species and density when compared with the other localities. However, the lowest diversity values indices in El Kanatoui and Hergla were attributed to the dominance of few herbivorous species such as A. helleri, A. ramondi and H. camptonyx due to the availability of food. In fact, the presence of epiphytes on host seagrass meadows raised habitat complexity, creating new attachment sites and shelter as well as increasing food supply for the associated fauna (Hall and Bell 1988; Martin-Smith 1993). Epiphytes also favour detritus accumulation and amplify surface area for the colonization of bacteria and microalgae (Hacker and Steneck 1990; James and Heck 1994; Leber 1985; Russo 1990), thus benefiting species that consume these food resources (Edgar 1990). In several seagrass ecosystems, algal epiphytes are found to be more attractive food for herbivores than the leaves themselves (Kitting et al. 1984; Orth and Van Montfrans 1984, Van Montfrans et al. 1984). In this study, epiphyte biomass was the factor that had the most direct bearing on diversity and species distribution, either acting alone or in conjunction with other variables like geographical position.

The dominant feeding category observed across all Tunisian seagrass meadows was herbivores mainly represented by $A$. helleri, A. ramondi and $H$. camptonyx. The dominance of herbivores was already observed at shallow water in summer (Gambi et al. 1992).

Analyses of similarity between the sampling stations based on the abundance of species showed three major assemblages whose distribution agreed mostly with that of gradient south/north. The first includes eastern and one of the southern meadows, the second group is composed by the northern localities and the last one is composed by the three replicates collected in Zarzis plage Sonia. Analysis of each assemblage revealed three species collected only in the northern meadows, seventeen species exclusively collected in the eastern meadows and two observed just in southern meadows. A previous study has shown that some species have a limited geographical distribution along the Tunisian coasts (Zakhama-Sraieb et al. 2009).

The structure of the third assemblage seems to be influenced by the presence of two lessepsian amphipods species Elasmopus pectinicrus and Stenothoe gallensis, recorded since 2006 in Zarzis Sonia plage meadow (Zakhama-Sraieb and Charfi-Cheikhrouha 2010). The presence of the lessepsian species seems to change the community structure of amphipod fauna. The decrease of abundance of A. helleri in Zarzis plage Sonia suggests the substitution of these species by the lessepsian ones.

In conclusion, it is evident that the Posidonia system is characterized by higher species richness and abundance. The architecture of Posidonia creates many microhabitats especially for epiphytic algae, therefore creating refuge and food resource for diverse forms of invertebrates. A group of amphipods, collected routinely from several Posidonia oceanica meadows around the Mediterranean coasts, could be considered as characteristic of this ecosystem. However, the characteristics of some Posidonia oceanica meadows and the presence of alien species can modify that community structure. Further studies in other seasons of the year should be conducted to survey the dynamics of the amphipod community in the south of Tunisia meadows.

Acknowledgments The authors want to express their gratitude to Professor Geoff Moore for revision of the English. Thanks are due to Dr Maria Beatrice Scipione, Maria Cristina Gambi and three anonymous referees who helped to improve the quality for the manuscript.

\section{References}

Bell JD, Harmelin-Vivien ML (1983) Fish fauna of French Mediterranean Posidonia oceanica seagrass meadows. 2 Feeding habits. Tethys 11:1-14

Bellan Santini D (1980) Relationship between populations of amphipods and pollution. Mar Poll Bull 11:224-227

Bellan Santini D (1981) Influence des pollutions sur les peuplements d'Amphipodes dans les biocénoses des algues photophiles. Tethys 10:185-194

Boudouresque CF, Bernard G, Bonhomme P, Charbonnel E, Diviacco G, Meinesz A, Pergent G, Pergent-Martini C, Ruitton S, Tunesi L (2006) Préservation et conservation des herbiers à Posidonia oceanica. Ramoge Publications, France, p 102

Chessa LA, Fresi E, Soggiu L (1983) Preliminary data on consumer's food web in a Posidonia oceanica (L.) Delile bed. Rapp Comm Int Mer Médit 28(3):159-160

Chevreux E (1910) Note sur les Crustacés Amphipodes d'Algérie et de Tunisie. Bull Soc Hist Nat de l'Afrique du Nord 2(9):135-137

Chevreux E (1911) Campagnes de la Melita: les Amphipodes d'Algérie et de Tunisie. Mem Soc Zoo France 23:145-285

Clarke KR, Warwick RW (1994) Change in marine communities: An approach to statistical analysis and interpretation. Natural Environmental Research Council, UK, p 144

Conradi M, Lopez-Gonzalez PJ, Garcia-Gomez JC (1997) The amphipod community as a bioindicator in Algeciras Bay (Souther Iberian Peninsula) based on a spatio-temporal distribution. P.S.Z.N. Mar Ecol 18:97-111 
Diviacco G (1988) ICrostacei Anfipodi di alcune praterie di P. oceanica pugliesi. Thalassia Salentina 18:131-139

Edgar GJ (1990) Population regulation, population dynamics and competition amongst mobile epifauna associated with seagrass. J Exp Mar Biol Ecol 144:205-234

Gambi MC, Lorenti M, Russo GF, Scipione MB, Zupo V (1992) Depth and seasonal distribution of some groups of the vagile fauna of the Posidonia oceanica leaf stratum: structural and trophic analyses. Mar Ecol 13:17-39

Gesteira Gomez, Dauvin (2000) Amphipods are good bioindicators of the impact of oil spills on soft-bottom macrobenthic communities. Mar Poll Bull 40(11):1017-1027

Guerra-Garcia JM, Garcia-Gomez JC (2001) The spatial distribution of Caprellidea (Crustacea: Amphipoda): a stress bioindicator in Ceuta (North Africa, Gibraltar area). P.S.Z.N.I. Mar Ecol 22(4):357-367

Hacker SD, Steneck RS (1990) Habitat architecture and bodysizedependent habitat selection of a phytal amphipod. Ecology 71:2269-2285

Hall MO, Bell SS (1988) Response of small motile epifauna to complexity of epiphytic algae on seagrass blades. J Mar Res 46:613-630

James PL, Heck KL Jr (1994) The effects of habitat complexity and light intensity on ambush predation within a simulated seagrass bed. J Exp Mar Biol Ecol 176:187-200

Katagan T, Kocatas A, Szegin M (2001) Amphipod biodiversity of shallow water Posidonia oceanica (L.) Delile, 1813 meadows in the Aegean coasts of Turkey. Acta Adr 42(2):25-34

Kitting CL, Fry B, Morgan MD (1984) Detection of inconspicuous epiphytic algae supporting food webs in seagrass meadows. Oecologia 62:145-149

Leber KM (1985) The influence of predatory decapods, refuge, and microhabitat selection on seagrass communities. Ecology 66:1951-1964

Ledoyer M (1962) Etude de la fauna vagile des herbiers superficiels de Zosteracées et quelques biotopes d'algues littorales. Rec Trav Stn Mar Endoûme 39:117-235

Ledoyer M (1966) Ecologie de la faune vagile des biotopes Méditerranéens accessibles en scaphandre autonome. II. Données analytiques sur les herbiers de phanérogames. Rec Trav Sta Mar Endoûme 41(57):135-164

Martin-Smith KM (1993) Abundance of mobile epifauna: the role of habitat complexity and predation by fishes. J Exp Mar Biol Ecol 174:243-260

Mazzella L, Scipione MB, Buia MC (1989) Spatio-temporal distribution of algal and animal communities in a Posidonia oceanica meadow. P.S.Z.N.I: Mar Ecol 10:107-129

Orth RJ, van Montfrans J (1984) Epiphyte-seagrass relationship with an emphasis on the role of micrograzing: a review. Aquat Bot 18:43-69

Russo AR (1990) The role of seaweed complexity in structuring Hawaiian epiphytal amphipod communities. Hydrobiologia 194:1-12

Sanchez Jerez P, Barbera Cebrian B, Ramos Espla AA (1999) Comparison of the epifauna spatial distribution in P. oceanica, C. nodosa and unvegetated bottoms: Importance of meadow edges. Oceanol Acta 20(4):391-405
Scipione MB (1998) Amphipod biodiversity in the foliar stratum of shallow-water Posidonia oceanica beds in the Mediterranean Sea. In: Proceedings of the fourth Crustacean Congress, Crustacean and biodiversity crisis. Koninklije Brill NV, Leiden 1, pp 649662

Scipione MB, Fresi E (1984) Distribution of Amphipod Crutaceans in P. oceanica (L.) Delile foliar stratum. In: 1st International workshop P. oceanica beds. In: Boudouresque CF, Jeudy de Grissac A, Fresi E (eds) Gis Posidonia publ. Fr 1: 319-329

Scipione MB, Mazzella L (1992) Epiphytic diatoms in the diet of crustacean amphipods of Posidonia oceanica leaf stratum. Oebalia 17(Suppl):409-412

Scipione MB, Fresi E, Wittmann KJ (1983) The vagile fauna of Posidonia oceanica (L.) Delile foliar stratum: a community approach. Rapp Comm Int Mer Médit Monaco 28(3):141-142

Scipione MB, Gambi MC, Lorenti M, Russo GF, Zupo V (1996) Vagile fauna of the leaf stratum of Posidonia oceanica and Cymodocea nodosa in the Mediterranean Sea, Seagrass Biology. In: Proceedings of an international workshop. Rottnest Island, Western Australia, pp 249-260

Thomas JD (1993) Biological monitoring and tropical biodiversity in marine environments: a critique with recommendations, and comments on the use of amphipods as bioindicators. J nat Hist London 27:795-806

Van Montfrans J, Wetzel RL, Orth RJ (1984) Epiphyte-grazers relationships in seagrass meadows: consequences for seagrass growth and production. Estuaries 7:289-309

Virnstein RW (1987) Seagrass-associated invertebrate communities of the Southeastern U.S.A.: a review. In: Durako MJ, Phillips RC, Lewis RR III (eds) Proceedings of the Symposium on Subtropical-Tropical Seagrasses of the Southeastern United States. Florida Marine Research Publ, Florida, pp 89-116

Zakhama-Sraieb R, Charfi-Cheikhrouha F (2010) First record of two lessepsian amphipods in Tunisia: Elasmopus pectenicrus and Stenothoe gallensis. J Mar Biol Assoc UK (in press)

Zakhama-Sraieb R, Sghaïer YR, Charfi-Cheikhrouha F (2006a) Ecologie des Amphipodes Gammaridea associés à l'herbier de posidonie de Mahdia. Actes des $6^{\text {èmes }}$ Congrès Maghrébin des Sciences de la Mer. Bull Inst Nat Sci Techn mer 10:45-48

Zakhama-Sraieb R, Sghaïer YR, Charfi-Cheikhrouha F (2006b) Is amphipod diversity related to the quality of Posidonia oceanica beds? Biol Mar Medit 13:174-180

Zakhama-Sraieb R, Sghaïer YR, Charfi-Cheikhrouha F (2008) Les Caprelles (Crustacea: Amphipoda) des côtes tunisiennes. Bull Soc Zoo France 133:149-157

Zakhama-Sraieb R, Sghaïer YR, Charfi-Cheikhrouha F (2009) Amphipod biodiversity of the Tunisian coasts: update and distributional ecology. JMBA2 Biodiversity Records, 2, e155 doi:10.1017/S1755267209990820 (published online)

Zakhama-Sraieb R, Karaa S, Bradai MN, Jribi I, Charfi-Cheikhrouha F (2010) Amphipod epibionts of the sea turtles Caretta caretta and Chelonia mydas from the Gulf of Gabès (central Mediterranean). JMBA2 Biodiversity Records, 3, e38 doi:10.1017/S1755267 210000333 (published online) 